\title{
PROBABILISTIC HAZARD ASSESSMENT, USING ARIAS INTENSITY EQUATION, IN THE EASTERN PART OF THE GULF OF CORINTH (GREECE)
}

\author{
Zygouri V. \\ University of Patras, Department of Geology, Laboratory of Structural Geology, 26500 Patras, Greece, \\ zygouri@upatras.gr
}

\begin{abstract}
Shallow earthquakes cause serious damage near the trace of faults. The growth of major cities in hazard prone areas and the public anxiety associated with risks in critical facilities has focused attention to those areas. The Gulf of Corinth constitutes an area prone to high seismicity. During the last 2000 years several strong seismic events have caused extensive collapses, death casualties and widespread landslide phenomena. Strong motion attenuation relationships are considered a significant parameter for any earthquake hazard analysis. Attenuation relationships used in probabilistic hazard assessments predict ground motions components (in this case arias intensity) as a function of source parameters (magnitude and mechanism), propagation path (fault distance) and site effects ( site class). In the eastern part of the Gulf of Corinth arias intensity equations were applied for a number of large $E$ - $W$ trending faults dominating the seismic potential of the area. Those faults have already been associated with landslide phenomena according to historic records and by using new methodologies a probabilistic approach of their behaviour has been accomplished for different recurrence intervals.
\end{abstract}

Key words: arias intensity, probabilistic hazard assessment, landslide phenomena, eastern gulf of Corinth.

\section{Introduction}

The historic seismicity of the Gulf of Corinth is well - described since is responsible for the destruction of ancient cities lying on the northern coasts of Peloponnese. However, the modern seismicity is equal violent and destructive (Ambraseys and Jackson, 1990, Papadopoulos et al., 2000, Papazachos and Papazachou, 2003). These abundant seismically produced hazards are accompanied by serious ground failures as described in the Alkyonides earthquakes (Koukis and Rozos, 1985) and in Pyrgos area (Koukouvelas et al., 1996). The north coast of Peloponnese and especially the eastern part of the Gulf appear a high relief that in combination with the high rate of sedimentation due to the rivers' flow can trigger potential slides and lateral spreads. However, little have been done regarding the estimation of this potential hazard (Koukis et al., 2009).

For this reason we applied strong motion attenuation relationships in the easternmost part of the Gulf of Corinth in order to conduct an earthquake hazard analysis for the most significant almost E - W trending faults. These faults show spectacular exposed surface traces and large cumulative slip. 

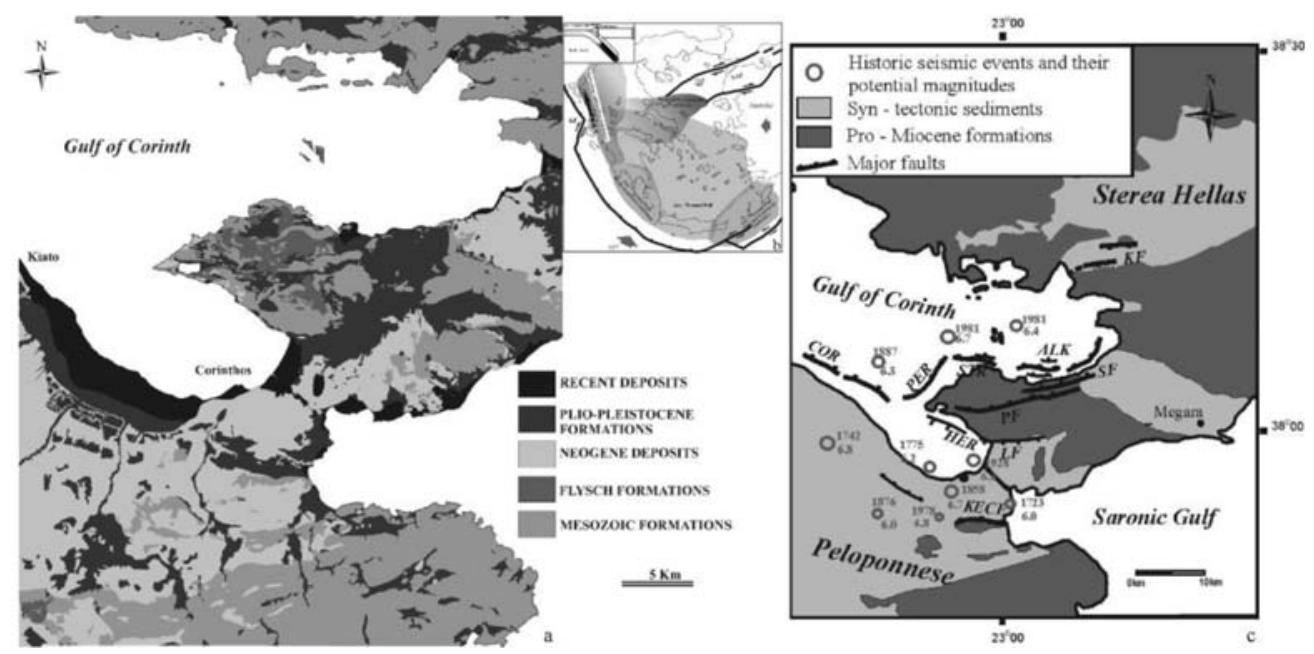

Fig. 1: a) Simplified stratigraphy map of the eastern part of the Gulf of Corinth Greece. b) Geological setting of the study area. c) Simplified map showing the main structural features along the eastern part of the Gulf, as well as the main historical seismic events. COR: Corinthos fault, KECF: Kechriaie fault, LF: Loutraki fault, HER: Heraion fault. PER: Perachora Fault, PF: Pissia Fault, SF: Skinos Fault, STR: Strava fault, ALK: Alkyonides Fault, and KF: Kaparelli Fault.

\section{Geological setting}

The Gulf trends WNW-ESE across the Hellenic mountain range which reaches an elevation of almost $2 \mathrm{~km}$ approximately perpendicular to the inherited structural grain of the Alpine orogenesis. Current rates of extension imply that this region is extended in N-S direction up to a rate of $15 \mathrm{~mm} / \mathrm{yr}$ (Briole et al., 2000), while at the eastern end of the Gulf the rate is reduced to a value of $6 \mathrm{~mm} / \mathrm{yr}$ (Avallone et al., 2004). Extensional deformation within the Gulf is inferred initiated in Pliocene and is primarily accommodated by $\mathrm{E}-\mathrm{W}$ trending faults (Doutsos and Kokkalas, 2001). These major faults have trace length in the order of $15-20 \mathrm{~km}$ and are compartmentalized into en-echelon segments, dipping at moderate angles (50-60 ) (Koukouvelas and Doutsos, 1996). The sedimentary processes are controlled by the tectonic activity creating high relief through seismic ruptures and suitable conditions for high sediment supply (see Zygouri et al., 2008 and references therein).

In the study area fluvial - lacustrine sediments are recognised in a transect from Kaparelli area through Perachora Peninsula and further south to the Corinthos region (Fig. 1, Collier and Dart, 1991; Bentham et al., 1991). The marine terraces that dominate the coastal zone of north Peloponnese is the result of the sea level changes in combination with the fault activity. At the inner part of the Gulf the sedimentary process consists of turbiditic currents and the development of deltaic fan near the river's mouths.

Historical and instrumental seismic catalogues in the eastern part of the Gulf of Corinth include records of at least twelve rupture events from 426 BC (Ambraseys and Jackson, 1990) up to the last destructive Alkyonides event in 1981 AD (King et al., 1985). In many cases these events triggered large landslides and/or liquefactions in coastal areas recorded in 1858 (Koustas, 1858) and in 1981 event (Koukis and Rozos, 1985). In many cases landslides are responsible for highly variable and significant numbers of casualties and damages after a strong earthquake, therefore, this paper aims to shed some light to the potential distribution of mass wasting induced by the earthquakes of five of main active faults of the eastern part of the Gulf. 
Table 1.

\begin{tabular}{|c|c|c|}
\hline \multicolumn{2}{|c|}{ Empirical relationships } & \multirow{2}{*}{$\begin{array}{c}\text { Reference } \\
\begin{array}{c}\text { Ambraseys and Jack- } \\
\text { son, } 1998\end{array}\end{array}$} \\
\hline Rupture & $M s=1.14 \log (L)+5.27$ & \\
\hline Magnitude & $M s=0.90 \log (L)+5.48$ & $\begin{array}{l}\text { Pavlides and Caputo, } \\
2004\end{array}$ \\
\hline $\begin{array}{l}\text { Magnitude - } \\
\text { Distance }\end{array}$ & $\log (\operatorname{Re})=-2.98+0.75 \mathrm{Ms}$ & $\begin{array}{l}\text { Papadopoulos and } \\
\text { Plessa, } 2000\end{array}$ \\
\hline \multirow{2}{*}{$\begin{array}{l}\text { Arias } \\
\text { Intensity }\end{array}$} & $\begin{array}{l}\ln I a=2.8-1.981(M-6)+20.72 \ln (M / 6)-1.703 \ln \left(\sqrt{R^{2}+8.78^{2}}\right)+ \\
{[0.454+0.101(M-6)] S c+[0,479+0.334(M-6)] S d-0.166 F n+0.512 F r}\end{array}$ & Travasarou et al. 2003 \\
\hline & $\log I a=-2.663+1.125 m-2.332 \log \left(\sqrt{R^{2}+h^{2}}\right)+0.028 S+0.2 F \pm 0.524$ & $\begin{array}{l}\text { Danciu and Tselentis, } \\
2007\end{array}$ \\
\hline
\end{tabular}

\section{Methodology}

\subsection{General}

In recent studies the distribution of mass wasting is recorded only after the strong seismic event occurred. However, recently many studies focus on the prediction of the potential distribution of ground movements induced by earthquakes before such a strong earthquake happens (Capolongo et al. 2002, Wang et al., 2008). For this reason many empirical relationships have been developed in order to describe this distribution (Travasarou et al, 2003, Danciu and Tselentis, 2007), based on worldwide earthquake records. According to Keefer (2002) three types of ground movements can be revealed after a strong motion earthquake: (1) falls and disrupted landslides, (2) coherent slides and (3) lateral spreads and liquefactions, depending on the susceptibility of the material, the slope surface, the distance from the earthquake epicenter and the magnitude of the earthquake. A measure of occurrence of landslides was firstly analyzed by Wilson and Keefer (1985) and modified by Keefer and Wilson (1989) based on the Arias (1970) seismic intensity relationship. According to this threshold intensity values of $0.11 \mathrm{~m} / \mathrm{sec}$ correspond to falls and disrupted landslides, values of $0.32 \mathrm{~m} / \mathrm{sec}$ to coherent slides and values of $0.54 \mathrm{~m} / \mathrm{sec}$ to lateral spreads and liquefactions. These threshold values can be applied to a broad range of geological environments including our study area. To avoid an overestimation of the real conditions corresponding to the area we select the method of logic tree application that is widely used in probabilistic seismic hazard analysis as a flexible tool that can capture the uncertainties included in the determination of seismogenic sources. The assessment of the hazard of earthquakes - induced landslides can be performed at different levels ranging from regional studies to site - specific evaluation of individual slopes.

For this study we used two empirical relationships widely applied in the Greek territory, which correlate the seismic magnitude with the fault rupture (Table 1). Secondly, we apply the relationship of Papadopoulos and Plessa (2000) that correlates the seismic magnitude with the distance in which site effects can be observed (Table 1). Following relationships were parts of a logic tree method applied in each major fault of the eastern domain of the Gulf of Corinth in order to calculate arias intensity as a landslide limit to strong motion attenuation. Despite the widespread use of the methodology especially in probabilistic seismic hazard analysis, guidelines on setting up logic trees and assigning weights to the branches are lacking in the current literature. In our study weights were based on the actual results that in many seismic sequences have been observed.

\subsection{Data analysis}

The data analysis includes the implementation of the above relationships on four major tectonic 
structures dominating the eastern part of the Gulf of Corinth. These are the Kechriaie fault (KECF), the Loutraki fault (LF), the Pissia fault, (PF) the Schinos fault (SF) and the Kaparelli fault (KF) that are associated to strong past earthquakes. These faults have a general WNW-ESE trend and moderate to high dip towards the NNE except from the Loutraki (LF) and the Kaparelli fault (KF) that dip SSW (Fig. 1c). Along their length the faults show spectacular fault scarps, triangular faulted facets and alluvial fans. These faults have been associated with the appearance of long seismic ruptures and they seem responsible of triggering secondary site effects such as landslides and lateral spreads.

The methodology of logic tree diagrams constitutes a visualisation and systematization mean of the estimation process of arias intensity, when the undertaking of many successive decisions is demanded. Each decision appears its own self - determined gravity. The logic tree diagrams include a number of branches representing different conditions or relationships. Thus, they allow a small percentage of uncertainty according to the weight of each decision. The construction of the following logic tree diagrams contains three main branches. At the first branch, there is an estimation of seismic magnitude according to Ambraseys and Jackson (1998) and Pavlides and Caputo (2004) relationships, with the later obtaining greater trust due to the use of only Greek data of extensional related earthquakes. At the second branch the maximum epicentral distance in which landslide effects appear, is estimated according to Papadopoulos and Plessa relationship (2000). At the third branch the relationships of Travasarou et al., (2003) and Danciu and Tselentis (2007) are calculated. This calculation is based on data analysis derived mostly from the Mediterranean region and in currently extending areas (similar geological, climatic and vegetation conditions). Another advantage of these relationships is the introduction of the impact of lithology on the determination of arias intensity.

Applying a logic tree diagram for the $7.8 \mathrm{~km}$ long KECF (Fig. 2a), the $10.1 \mathrm{~km}$ long LF (Fig. 2b) the 9.4km long PF (Fig. 2c), the 9.8km long SF (Fig. 2d) and the 9.7km long KF (Fig. 2e) we observe that the relationships of Pavlides and Caputo (2004) and Travasarou et al., (2003) fit best the real ground hazards observed during past strong earthquakes. From the logic tree diagrams the calculated values of arias intensity show that rock falls especially in Mesozoic limestones and lateral spreads in soft sediments are more than expected, while the Neogene formations seem more secure. In the area around KECF, many rockfalls are observed induced by strong seismic events since the orientation and the nature of rocks are not susceptible to falling. Similarly the LF is expected to produce rock falls and slides close to the spectacular uplifted footwall. In addition during the seismic event of 1928 the descriptions suggest a dust cloud generated from the rockfalls from Geraneia mount. At the same time the proximity of the fault to the Vouliagmeni Lake may be responsible for the appearance of lateral spreads over the bankings of the lake in case of seismic loading. The PISF and the SF produce subsidence of the north coast of Perachora Penisnsula. During the seismic sequence of 1981 (Hubert et al., 1996) seismic ground motion contributed to the emergence of rock falls and small in size slides in alluvial cones. At the same seismic sequence few lateral spreads were recorded especially in coastal area due to the activation of SF and KF.

Adapting the calculated values of arias intensity near the fault trace and combining these values with the limits provided by Keefer and Wilson (1989), the surface topography and the lithology formations an estimation of probable areas displaying ground failures can be determined. For this reason we produced in GIS environment theme maps concerning the slope angle and the simplified lithology of the eastern onshore part of the Gulf of Corinth. The lithology structure of the area comprises four main lithotypes. Recent deposits and coastal deltaic deposits are loose sediments, prone to plastic deformation and usually liquefied. Neogene deposits consist of sandstones, conglomerates and marls. They have medium cohesion and are prone to slides in areas of high topography. The fly- 


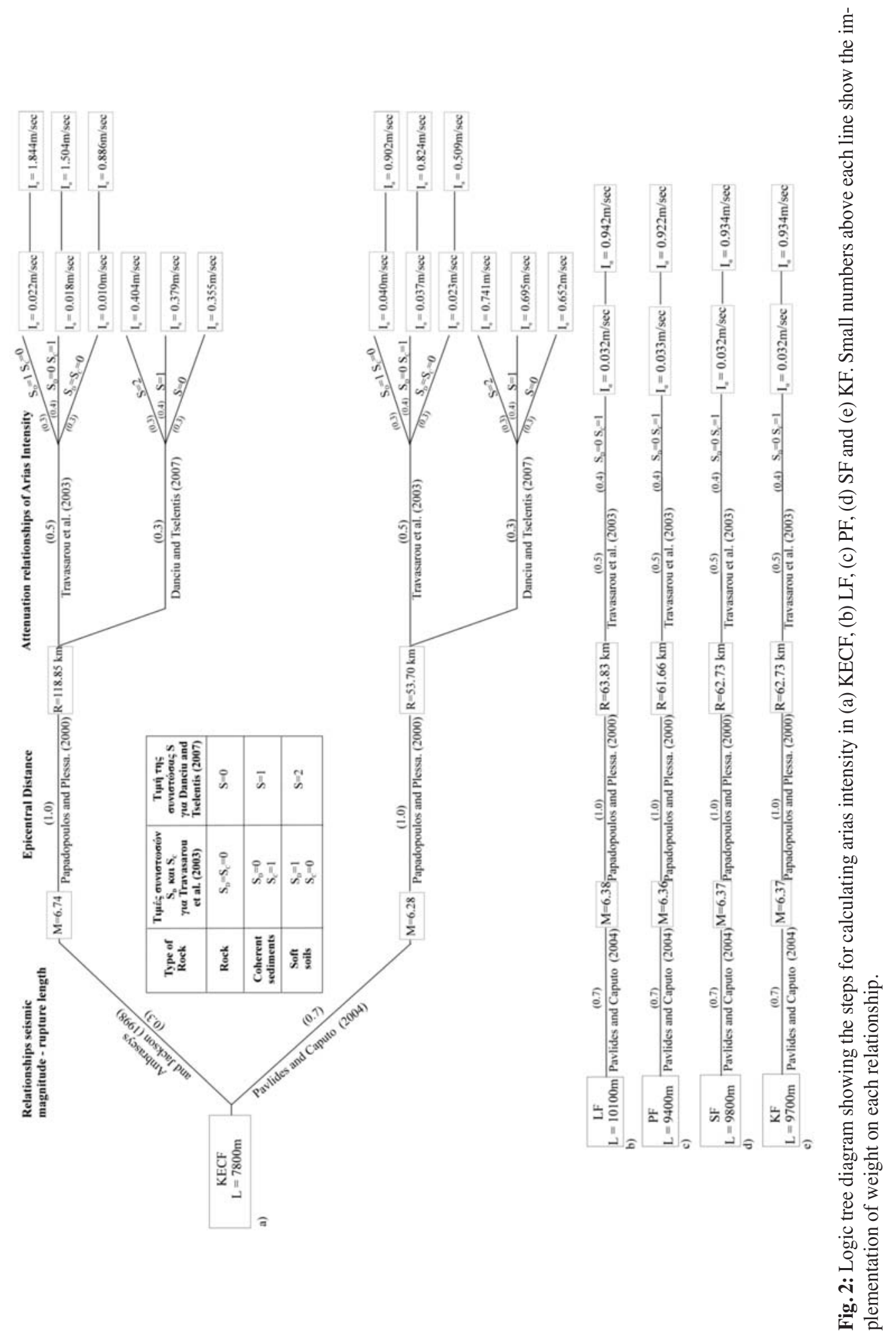



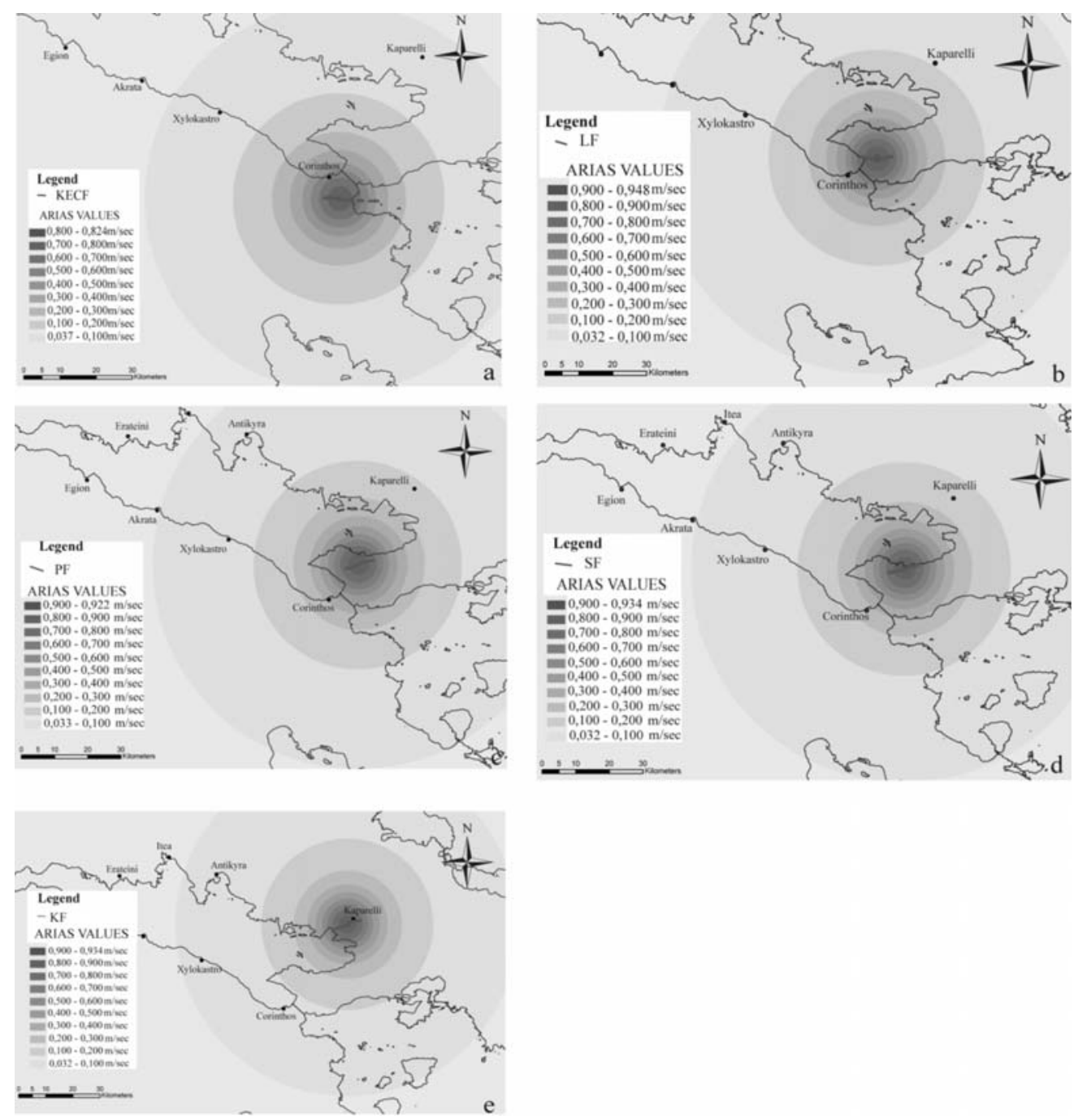

Fig. 3: a) Estimated values for arias intensity of a) KECF, b) LF, c) PF, d) SF and e) KF.

sch deposit characteristics are controlled by the thickness and the interchange between sandstone, conglomerate and clays, usually susceptible to slide. Finally, the Mesozoic formations include limestones, dolomites and ophiolites and they appear adequate geomechanical characteristics.

This kind of approach allows the detailed estimation of seismic hazard due to the motion of a seismic source. The above five faults represent well defined seismic sources with repetitive past activity. The estimation include the interaction between the values within the borders of epicentral area, the values of slope angle exceeding $15-20^{\circ}$ and what type of landslides can be triggered by the lithology. In the maps below according to the distribution of arias intensity values (Fig. 3), slope angle (Fig. 4) and lithology (Fig. 1a) the most hazardous areas are underlined according to the expected type of landslides (Fig. 5) derived from the thresholds of arias intensity for each type of landslide. 


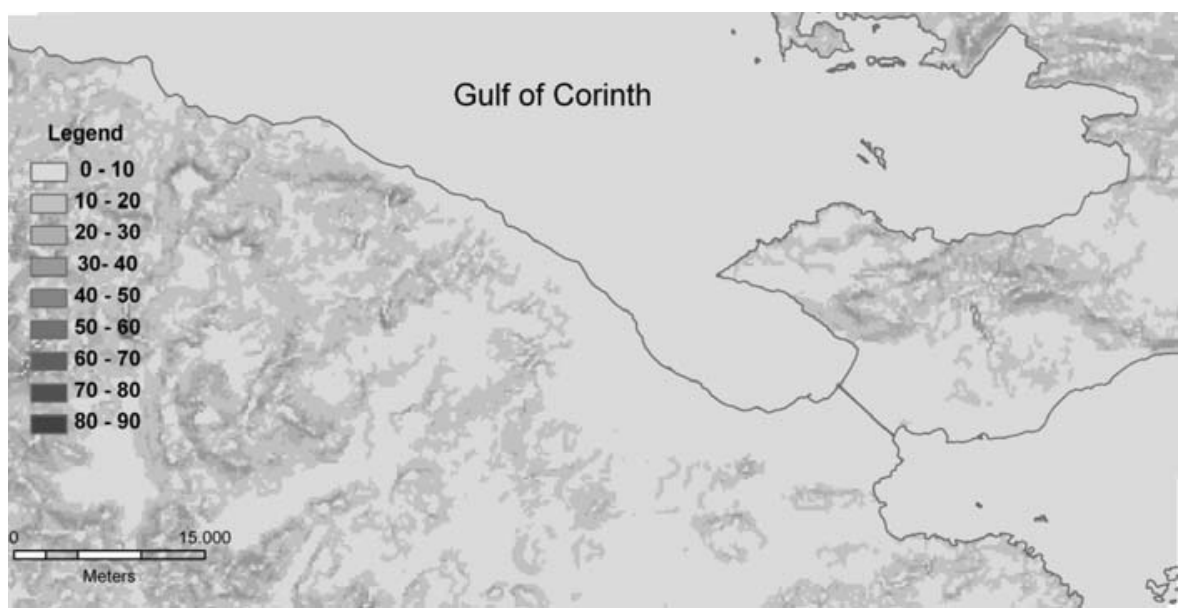

Fig. 4: Slope angle of the Gulf of Corinth.

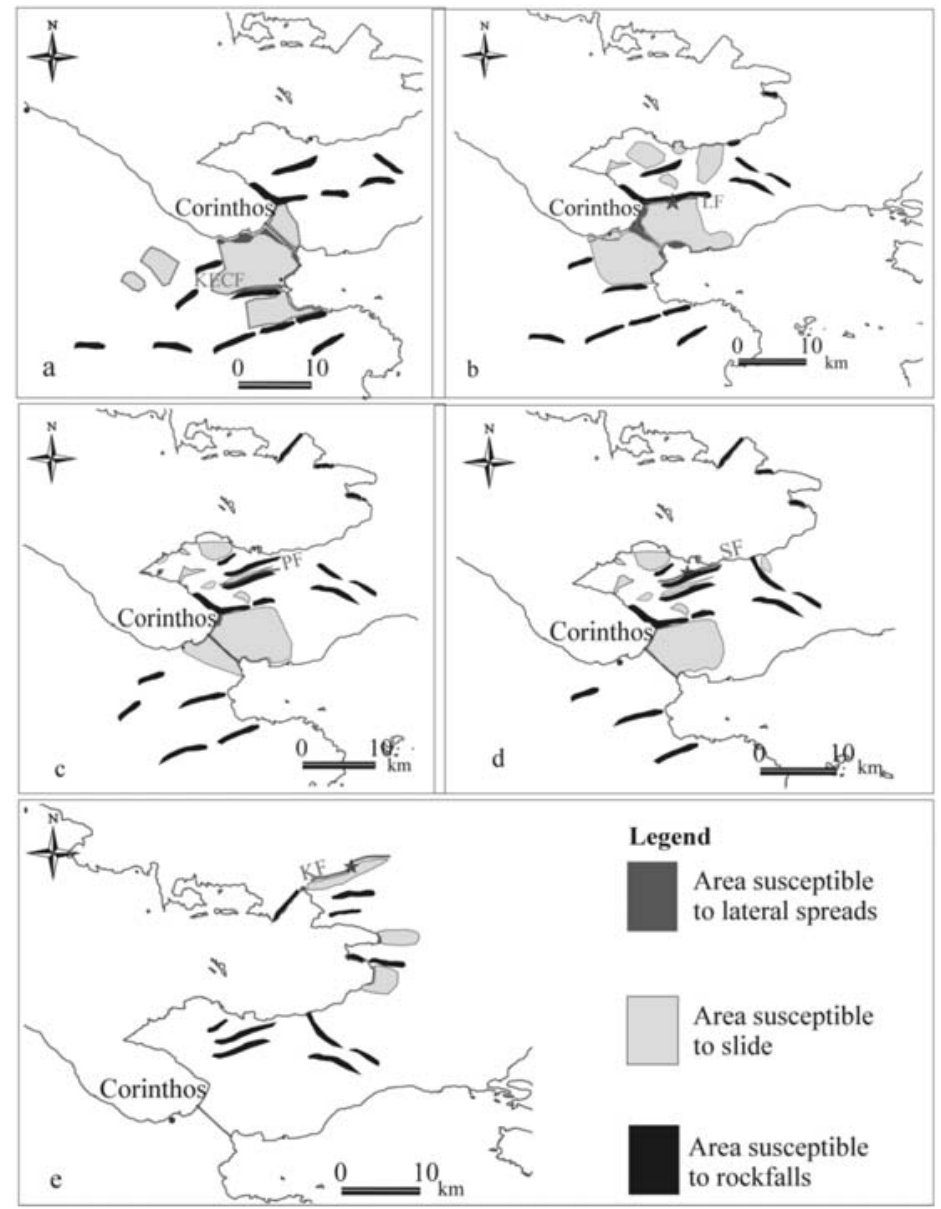

Fig. 5: Areas susceptible to landslide triggered by a) KECF, b) LF, c) PF, d) SF and e) KF seismic activation. 
As it can be seen in figure 5, numerous rockfalls are expected during each fault reactivation. The rockfalls occurred usually in highly slope Mesozoic deposits and extend in a large area far away from the epicenter due to the thresholds of arias intensity distribution. Moreover, the historic records confirm that many rockfalls occurred many km away from the actual epicenter. On the contrary the lateral spreads are more restricted in narrow low relief zones near the coastal area and especially in the area of the Isthmus Canal, while the coherent slides are favoured from the slope angle exceeding $15^{\circ}$ and the marly composition of lithology.

\section{Conclusions-Results}

The approaching method of seismic hazard assessment through logic - trees, the application of arias intensity and the selection of arias values as limits representing different types of landslides can be an ideal tool in describing potential ground hazards in areas of significant seismic activity. The interaction between slope angle, lithology and threshold values of arias intensity can define areas showing different types of landslides induced by strong earthquakes. The vast majority of the expected landslides in the eastern part of the Gulf of Corinth is the rockfalls. Most dangerous for provoking serious damages due to landslides are the KECF, the LF and the PF and SF. In those faults the expected damages are extending in a large area exceeding the length of the fault and unfortunately they are traced near significant urban areas and sensitive infrastructures for local economy. The great residential development that takes place in the coastal zone of the eastern part of the Gulf, increases the seismic hazard and at the same time the vulnerability of the constructions. Therefore, such seismic scenarios in a sense of logic - tree diagrams are essential for the estimation of seismic hazard and valuable tools for state decision makers.

\section{Acknowledgments}

VZ was financially supported by the research project (PENED) that was co - financed by E.U. - European Social Fund (80\%) and the Greek Ministry of Development - GSRT (20\%).

\section{References}

Ambraseys, N.N., Jackson J., 1990. Seismicity and associated strain of central Greece between 1890 and 1988. Geoph. J. Int. 101, 663-708.

Ambraseys, N.N., Jackson, J.A., 1998. Faulting associated with historical and recent earthquakes in the Eastern Mediterranean region. Geophys. J. Int. 133, 390-406

Arias, A., 1970. A measure of Earthquake Intensity, in Seismic Design of Nuclear Power Plants. In Hansen (ed.) the MIT Press, Cambridge, MA, 438-483.

Avallone, A., Briole, P., Agatza-Balodimou, A.M., Billiris, H., Charade, O., Mitsakaki, C., Nercessian, A., Papazissi, K., Paradissis P., Veis, G., 2004. Analysis of eleven years of deformation measured by GPS in the Corinth Rift Laboratory area. C. R. Geoscience 336, 301-311.

Bentham, P., Collier, R.E.L., Gawthorpe, R.L., Leeder, M.R., Prosser, S., Stark, C., 1991 . Tectono-sedimentary development of an extensional basin: the Neogene Megara Basin, Greece. J. Geol. Soc. London 148, 923-934.

Briole, P., Rigo, A., Lyon-Caen, H., Ruegg, J., Papazissi, K., Mistakaki, C., Balodimou, A., Veis, G., Hatzfeld, D., Deschamps, A., 2000. Active deformation of the gulf of Korinthos, Greece: results from repeated GPS surveys between 1990 and 1995. JGR 105, 25605-25625.

Capolongo, D., Refice, A., Mankelow, J., 2002. Evaluating earthquake-triggered landslide hazard at the basin scale through GIS in the Upper Sele river Valley. Surveys in Geophysics 23, 595-625. 
Collier, R.E.L, Dart, C.J., 1991. Neogene to Quaternary rifting, sedimentation and uplift in the Corinth basin, Greece. J. Geol. Soc. London 148, 1049-1065.

Danciu, L., Tselentis, G.A., 2007. Engineering ground-motion parameters attenuation relationships for Greece. Bull. Seismol. Soc. Am. 97, 162-183.

Doutsos, T., Kokkalas S. 2001. Stress and deformation in the Aegean region. Journal of Structural Geology 23, 455-472.

Hubert, A., King, G., Armijo, R., Meyer, B., Papanastasiou, D., 1996. Fault re-activation stress interaction and rupture propagation of the 1981 Corinth earthquake sequence. Earth Planet. Sci.Lett. 142, 573-585

Keefer, D., 2002. Investigating landslides caused by earthquakes - A historical review. Surveys in Geophysics, 23, 473-510.

Keefer, D.K., Wilson, R.C., 1989. Predicting earthquake - induced landslides, with emphasis on arid and semi - arid environments. In: Sadler, Morton (eds), Landslides in a semi Arid Environment 2, Inland Geol.Soc., 118-149.

King, G.C.P., Ouyang, Z.X., Papadimitriou, P., Deschamps, A., Gagnepain, L., Houseman, G., Jackson, J.A., Soufleris, C., Virieux, J., 1985. The evolution of the Gulf of Corinth (Greece): an aftershock study of the 1981 earthquakes. Geophys. J.R. Astron. Soc. 80, 677-693.

Koukis, G., Rozos, D., 1985. Engineering geological characteristics of the 1981 earthquakes in the Eastern Corinthian Gulf, Greece. Bull. Int. Assoc. Eng. Geol. 32, 91-95.

Koukis, G., Sabatakakis, N., Ferentinou, M., Lainas, S., Alexiadou, X., Panagopoulos, A., 2009. Landslide phenomena related to major fault tectonics: rift zone of Corinth Gulf, Greece. Bull. Eng. Geol. and the Env., 215-229

Koukouvelas, I.K., Doutsos, T., 1996. Implications of structural segmentation during earthquakes: The 1995 Egion earthquake, Gulf of Corinth, Greece. J. Struct. Geol. 18, 1381-1388.

Koukouvelas, I.K., Mpresiakas, A., Sokos, E., Doutsos, T., 1996. The tectonic setting and earthquake ground hazards of the 1993 Pyrgos earthquake, Peloponnese, Greece. J. Geol. Soc. London 152, 39-49.

Koustas, G., 1858. Earthquake of Corinthos. Pandora 8, 225-229 (in Greek).

Papadopoulos, G., Plessa, A., 2000. Magnitude - Distance relations for earthquake - induced landslides in Greece. Eng. Geol. 58, 251-270.

Papadopoulos, G., Vassilopoulou A., Plessa, A., 2000. A new catalogue of historical earthquakes in the Corinth rift, Central Greece: 480 BC - AD 1910. In: Historical Earthquakes and Tsunamis in the Corinth rift, Central Greece. National Observatory of Athens, Institute of Geodynamics (G. Papadopoulos ed.),Publication No 12, 9-119. National Observatory of Athens, Athens.

Papazachos, B.C., Papazachou, C., 2003. The earthquakes of Greece. Ziti, Thessaloniki.

Pavlides, S., Caputo, R., 2004. Magnitude versus faults' surface parameters: Quantitative relationships from the Aegean Region. Tectonophysics 380, 159-188.

Travasarou, T., Bray, J.B., Abrahamson, A., 2003. Empirical attenuation relationship for Arias Intensity. Earthquake Eng. and Struct. Dynamics 32, 1133-1155.

Wang, H., Wang, G., Wang, F., Sassa, K., Chen Y. 2008. Probabilistic modelling of seismically triggered landslides using Monte Carlo simulations. Landslides, 5, 387-395.

Wilson, R.C., Keefer, D.K., 1985. Predicting Areal Limits of earthquake - induced Landsliding. In: Ziony (ed.) Earthquake Hazards in the Los Angeles region - An earth science perspective U.S.G.S. Professional Paper 1360, 317-345.

Zygouri, V., Verroios, S., Kokkalas, S., Xypolias, P., Koukouvelas, I.K., 2008. Scaling properties within the Gulf of Corinth, Greece; comparison between offshore and onshore active faults. Tectonophysics 453, 193-210. 
